\title{
Diffuse neurofibroma - An uncommon cause of alopecia*
}

\author{
Neurofibroma difuso - Uma causa rara de alopécia
}

Vasco Coelho Macias ${ }^{1}$

Margarida Rafael ${ }^{2}$

Cândida Fernandes ${ }^{3}$

Joaninha Costa Rosa ${ }^{4}$

DOI: http://dx.doi.org/10.1590/abd1806-4841.20132170

\begin{abstract}
Although infrequent, alopecia can be caused by benign cutaneous tumours. Neurofibromas are common benign tumors that originate in the peripheral nerve sheath. Diffuse neurofibroma is a rare variant of neurofibroma that is thought to occur mainly in the head and neck of children and young adults. Histology generally shows an infiltrative tumor, composed of spindle cells in the dermis and subcutaneous tissue. Despite being rare, malignant transformation has been reported. The association between diffuse neurofibromas and neurofibromatosis type 1 still remains to be determined since some authors question the low incidence usually described. We report the case of a 42-year-old man who had a diffuse neurofibroma on the scalp presenting as alopecic plaques.
\end{abstract}

Keywords: Alopecia; Neurofibroma; Scalp

Resumo: Apesar de infrequente, a alopecia pode ser causada por tumores cutâneos benignos. Os neurofibromas são neoplasias benignas comuns com origem na baínha externa dos nervos. O neurofibroma difuso é uma variante rara de neurofibroma que ocorre tipicamente na cabeça e pescoço de crianças e adultos jovens. Histologicamente caracteriza-se por um tumor infiltrativo, composto por células fusiformes, localizado na derme e tecido celular subcutâneo. Apesar de rara, a transformação maligna já foi descrita. A associação dos neurofibromas difusos e neurofibromatose tipo 1 ainda não está determinada dado que alguns autores contestam a baixa incidência habitualmente referida. Descrevemos o caso de um homem de 42 anos com um neurofibroma difuso do couro cabeludo com aprasentacao de placas de alopecia.

Palavras-chave: Alopecia; Couro cabeludo; Neurofibroma

\section{INTRODUCTION}

Alopecia may be secondary to different inflammatory diseases, nutritional deficiencies, anemia and infections. More infrequently, malignant and benign cutaneous neoplasms or metastasis of the scalp can cause it. Neoplasm-related alopecia may be due to neoplastic infiltration of the pilosebaceous unit or tumor-induced inflammatory response that leads to dermal fibroplasia. ${ }^{1}$

Schwannoma and neurofibroma are the most common benign tumors of the nerve sheath. The latter represents approximately $5 \%$ of all benign soft-tissue tumors in large surgical series and is usually divided in three different types: localized, plexiform and diffuse.

Diffuse neurofibroma is a rare form of neurofibroma reported to occur primarily in children and young adults. It generally presents as a variably sized area of marked dermal and subcutaneous thickening, most often in the head and neck regions. ${ }^{2,3}$

We present the case of a 42-year-old patient with a diffuse neurofibroma on the scalp presenting as alopecic plaques.

\section{CASE REPORT}

A 42-year-old Caucasian male presented with an asymptomatic swelling in the frontal and left temporal regions of the scalp. The swelling had been present since he was 17 years old, gradually enlarging since then. The first skin biopsy, at the age of 29, was inconclusive and the patient was lost to follow-up; however, due to the continued growth of the swelling and loss of overlying hair, he returned years later for reevaluation.

\footnotetext{
Received on 02.10.2012.

Approved by the Advisory Board and accepted for publication on 28.10.2013.

* Work performed at the Department of Dermatology, Portuguese Institute of Oncology Francisco Gentil (IPOLFG) - Lisbon, Portugal

Conflict of interest: None

Financial funding: None

MD, Resident physician - Department of Dermatology and Venereology, Hospital de Curry Cabral, Lisbon, Portugal.

Consultant - Department of Dermatology, Instituto Português de Oncologia Francisco Gentil, Lisbon, Portugal.

Consultant - Department of Dermatology and Venereology, Hospital de Curry Cabral, Lisbon, Portugal.

Consultant - Department of Pathological Anatomy, Instituto Português de Oncologia Francisco Gentil, Lisbon, Portugal.

(C2013 by Anais Brasileiros de Dermatologia
} 
He had no relatives with history of neurofibromatosis (NF).

Physical examination revealed a multicentric tumor with ill-defined borders composed of three confluent plaques with $9 \mathrm{~cm}, 8 \mathrm{~cm}$ and $6 \mathrm{~cm}$ diameter located in the frontal and left temporal regions of the scalp (Figure 1). The tumor was soft on palpation and there was loss of hair on the overlying, hyperpigmented skin. There were no changes in the underlying bone nor was there any bruit. The remaining physical examination aspects were unremarkable and no other NF features were found. Ophthalmologic examination excluded the presence of Lysch nodules. The patient showed no cognitive impairment. At this time, the diagnostic hypotheses were lipoma, venous malformation and low-grade malignancy.

Ultrasound showed an ill defined, diffusely hyperechoic mass with $0.9 \mathrm{~cm}$ thickness. Doppler revealed multiple vascular structures, suggestive of hemangioma. Cranial computed tomography (CT) showed no intracranial extension (Figure 2). A biopsy specimen of the tumor revealed spindle cells with oval nuclei in a myxoid background. The lesion was located in the dermis and subcutaneous tissue; skin appendages were scarce in the deeper dermis. No Meissner bodies were seen. (Figures 3 and 4) These findings were suggestive of a diffuse neurofibroma and the patient was submitted to surgical excision of the tumor with a temporal rotation flap and a free skin graft. The tumor was completely excised and the postoperative period was uneventful. Histopathological examination confirmed a diffuse neurofibroma. No recurrence was recorded during the first 6 months of follow-up.

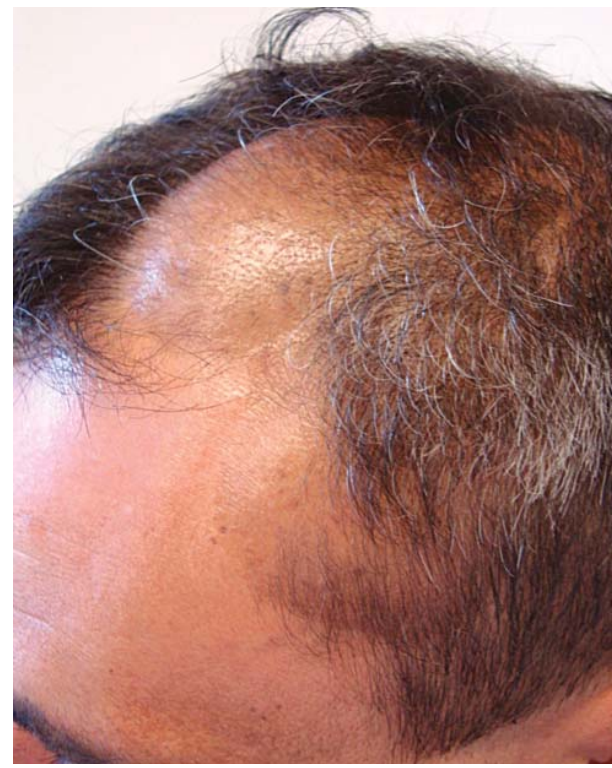

Figure 1:

Clinical aspect of the scalp lesions showing 3 confluent plaques located in the frontal and left temporal regions. Note the alopecia and light brown diffuse hyperpigmentation

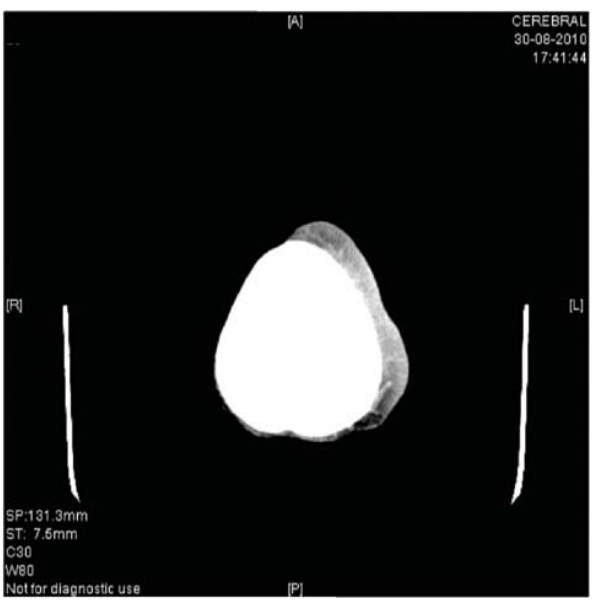

Figure 2: Computed tomography image showing a lobulated mass encircling almost half the cranium

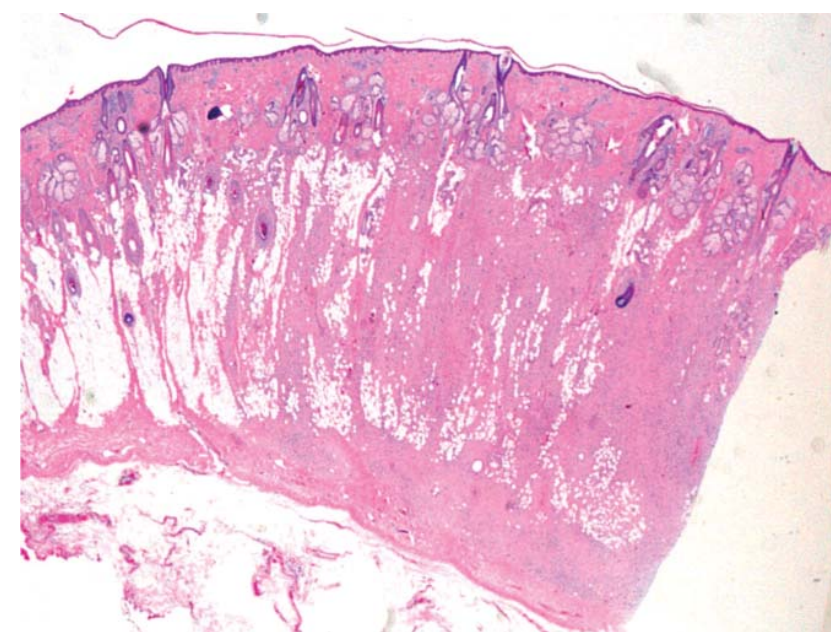

FIGURE 3: The biopsy specimen of the tumor showed an infiltrative lesion occupying the entire dermis into the subcutaneous tissue. Skin appendages were dislodged into the superficial dermis

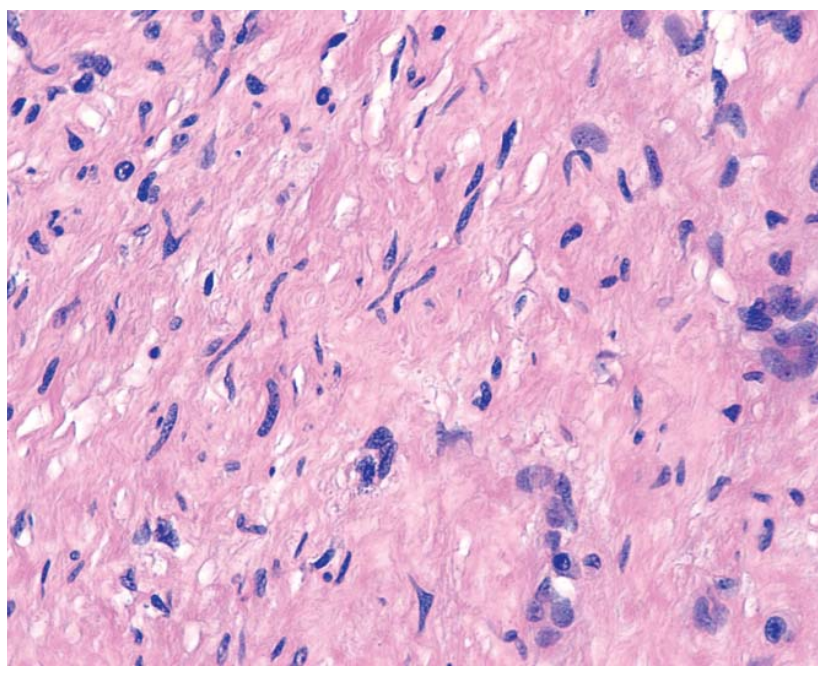

Figure 4: The tumor was composed of spindle cells, some with wavy nuclei, surrounded by a myxoid background 


\section{DISCUSSION}

Neurofibromas are benign tumors of the peripheral nerves that have a neuroectodermal origin. They originate in the external nerve sheath and are characterized by the proliferation of Schwann cells, perineural cells and endoneural fibroblasts. ${ }^{4}$ Localized and plexiform neurofibromas are well known subtypes: the first one is the most common and clinically they are skin-colored dome-shaped or pedunculated papules that display the pathognomonic "buttonhole" sign. They can be sporadic or NF-associated. Plexiform neurofibromas diffusely involve single or multiple nerve branches, imparting a wormy sensation on palpation; they can reach considerable size and are usually associated with NF. Diffuse neurofibromas, conversely, are a rare subtype. They are usually single lesions, with progressive enlargement and infiltrative growth pattern, simulating malignant tumors. Although they were classically reported to occur in the head and neck regions of children and young adults, recent series reported the trunk and extremities as the commonest locations, each accounting for slightly more than one third of all diffuse neurofibromas. ${ }^{4.8}$ Intracranial extension of the extracranial variety of this tumor has rarely been reported $^{7}$ and malignant transformation is believed to be rare, however pain and enlargement may proclaim it. $^{2}$ Although Megahed and Hassel et al reported higher association rates, it is estimated that about $10 \%$ of these tumors are associated with NF$11^{2,4,5,8,9}$ Some authors attribute the lower estimated incidence of NF-1 to the young age of patients with diffuse neurofibroma, which often precludes a reliable diagnosis of NF-1. ${ }^{3}$

Imaging studies are helpful in defining the anatomic relationships with adjacent structures. Ultrasound, CT and magnetic resonance imaging are well suited to define the extent of disease and can even suggest the diagnosis of diffuse neurofibroma. ${ }^{8-10}$

On histopathological examination, diffuse neurofibromas are ill-defined tumors that diffusely infil- trate the dermis and subcutaneous tissue, often extending along connective tissue septa, without destroying the normal structures. They are composed of elongated spindle-shaped cells with round to fusiform nuclei and eosinophilic cytoplasm within a loose matrix of fibrillary collagen. Meissner bodies, a characteristic feature of diffuse neurofibromas, are not always present. Fat and ectatic blood vessels may be dominant features. Expression of S-100 protein is characteristic and a sensitive, but non-specific, marker.

Currently, surgical excision is the best treatment option for isolated neurofibromas, especially for large, painful or function-compromising lesions. However, as reported in the present case, surgical approach can be challenging, mainly due to the tumor's dimensions. Because of the rich vascular supply, preoperative angiogram and intra-arterial embolization may be helpful in reducing the risk of hemorrhage. ${ }^{6,7}$ Given the infiltrative growth pattern and multicentricity of the tumor, clinical recurrences are common, even after complete surgical excision. Because of the recurrence potential, malignant transformation and NF development possibility, yearly follow-up is recommended.

In the reported case, the presentation of diffuse neurofibroma as alopecic plaques on the scalp is illustrative of its indistinctive clinical characteristics. The mechanism of neurofibroma-associated alopecia is unknown. Although neurofibromas usually surround, rather than destroy, skin appendages, in the present case skin biopsy showed neurofibroma occupying the entire dermis and "pushing" hair follicles towards the upper dermis (Figure 3). Authors speculate this might be the cause of alopecia. Clinical history, physical examination and imaging studies are important to exclude associated NF. Diffuse neurofibromas should be considered in the differential diagnoses of scalp tumors.] 


\section{REFERENCES}

1. Scheinfeld N. Review of scalp alopecia due to a clinically unapparent or minimally apparent neoplasm (SACUMAN). Acta Derm Venereol. 2006;86:387-92.

2. van Zuuren EJ, Posma AN. Diffuse neurofibroma on the lower back. J Am Acad Dermatol. 2003;48:938-40.

3. Yoo KH, Kim BJ, Rho YK, Lee JW, Kim YJ, Kim MN, et al. A Case of Diffuse Neurofibroma of the Scalp. Ann Dermatol. 2009;21:46-8.

4. Megahed M. Histopathological variants of neurofibroma: a study of 114 cases. Am J Dermatopathol. 1994;16:486-95

5. Beggs I, Gilmour BHM, Davie RM. Diffuse neurofibroma of the ankle. Clin Radiol. 1998:53:755-9.

6. de Varebeke SJ, De Schepper A, Hauben E, Declau F, Van Marck E, Van de Heyning PH. Subcutaneous diffuse neurofibroma of the neck: a case report. J Laryngol Otol. 1996;110:182-4.

7. $\quad$ Ergün SS, Emel E, Karabekir S, Büyükbabani N. Extracranial diffuse neurofibroma with intracranial extension. Plast Reconstr Surg. 2000;105:801-3.

8. $\quad$ Hassell DS, Bancroft LW, Kransdorf MJ, Peterson JJ, Berquist TH, Murphey MD, et al. Imaging Appearance of Diffuse Neurofibroma. AJR Am J Roentgenol. 2008;190:582-8.

9. Kumar BS, Gopal M, Talwar A, Ramesh M. Diffuse neurofibroma of the scalp presenting as circumscribed alopecic patch. Int J Trichology. 2012;2:60-2.

10. Huang GS, Huang CW, Lee HS, Chang WC, Lee CH, Leu NH, et al. On the AJR viewbox. Diffuse neurofibroma of the arm: MR characteristics. AJR Am J Roentgenol. 2005;184:1711-2.
MAILING ADDRESS:

Vasco Coelho Macias

Serviço de Dermatologia e Venereologia

Hospital de Curry Cabral

Rua da Beneficência, n8, 1069-166 - Lisboa - Portugal

E-mail:vmcmacias@gmail.com

How to cite this article: Macias VC, Rafael M, Fernandes C, Costa Rosa J. Diffuse neurofibroma - An uncommon cause of alopecia. An Bras Dermatol. 2013;88(6 Suppl 1):S166-9. 